\title{
THE NATURE OF THE CIRCULATING THYROID HORMONE IN GRAVES' DISEASE ${ }^{1}$
}

\author{
BY I. N. ROSENBERG 2 \\ (From the New England Center Hospital and the Department of Medicine, Tufts College \\ Medical School, Boston)
}

(Submitted for publication July 13, 1950; accepted, October 2, 1950)

Numerous clinical investigations have demonstrated that the concentration of plasma proteinbound iodine or serum precipitable iodine is a reliable index of thyroid gland activity, the values correlating well with the basal heat production (1) and with clinical evaluation of thyroid function (2). In myxedema the concentration is below the euthyroid range and in hyperthyroidism abnormally high values are found (3) which revert to normal following treatment of the disease by surgery $(4)$ or by antithyroid drugs $(5,6)$. The serum concentration of protein-bound radioactive iodine in patients with hyperthyroidism has been found to be significantly higher than in euthyroid individuals 24 or more hours after an oral dose of $I^{131}(7,8)$. Similar observations have been made in animal studies; rats receiving thyrotropin injections show plasma concentrations of proteinbound $\mathrm{I}^{127}$, and, if injected with tracer $\mathrm{I}^{181}$, of protein-bound $\mathrm{I}^{131}$ which are higher than normal controls, while in thyroidectomized animals the corresponding figures for protein-bound iodine in both isotope forms are very low (9).

The chemical nature of the plasma protein-bound iodine in normal man has been the subject of several studies. Lerman (10) demonstrated by serological methods that human blood contains no detectable thyroglobulin. Trevorrow (11) reported that all the iodine in plasma may be extracted free of protein by acetone, ethanol or butanol, and subsequent application to human plasma $(12,13)$ and to plasma previously subjected to peptic digestion (14) of the Leland and Foster (15) method for separation of thyroxine from iodide and diiodotyrosine, showed that 70 to 90 per cent of the total iodine has solubility proper-

${ }^{1}$ Aided in part by grants to Dr. E. B. Astwood from the Committee on Endocrinology of the National Research Council and from the American Cyanamid Company.

2 U. S. Public Health Service Postdoctoral Research Fellow. ties similar to thyroxine in being extractable by $n$-butanol and not re-extractable by alkali. Butanol fractionation of whole blood of euthyroid individuals following prolonged alkaline hydrolysis has led to the recovery of 40 to 60 per cent of the organic iodine in the thyroxine-like fraction (16), but these values are presumably too low since the hydrolysis is destructive of considerable thyroxine $(12,15)$. Thyroxine added to plasma becomes non-dialyzable $(11,12)$, is quantitatively precipitated with the proteins $(3,11,12)$, and can be largely recovered by butanol extraction $(11,12)$; added diiodotyrosine is only partially. recovered in the protein precipitate (3) and is extracted from butanol by base (12).

Studies on the plasma iodine of normal animals have yielded more definite evidence regarding its nature than have corresponding human investigations. Taurog and Chaikoff (12) showed that 84 per cent of the plasma iodine, and 66 per cent of the $\mathrm{I}^{131}$ of rats previously injected with radioactive iodine, can be recovered in the alkaliwashed butanol extract, that thyroxine added to the extract containing ${ }^{131}$ retains constant specific activity after repeated crystallizations and that the distribution coefficient of the radioactivity between immiscible solvents equals that of thyroxine, evidence very suggestive of the identity of thyroxine and a large fraction of the plasma iodine. Recent studies employing radioautography of paper chromatograms of butanol extracts of plasma from rats previously (24-48 hours) injected with radioactive iodine have confirmed this view. Laidlaw (17)-observed spots corresponding to thyroxine and iodide as the sole radioactive components of plasma, the thyroxine constituting approximately 80 per cent of the total protein-bound $\mathrm{I}^{131}$. Taurog and his associates (18) also concluded that thyroxine and iodide were the chief components. Gross and his co-workers (19) observed activity predominantly at the area corre- 
sponding to thyroxine, with very low activity at the diiodotyrosine and monoiodotyrosine spots; in addition, direct chromatography of plasma indicated that the radioactivity travelled with the proteins. The evidence derived from these animal studies strongly suggests that the circulating thyroid hormone is thyroxine in loose, non-peptide association with the plasma proteins.

Salter and his associates have investigated the nature of the protein-bound iodine in patients with myxedema and hyperthyroidism. In euthyroid and hyperthyroid individuals, butanol fractionation of plasma following peptic hydrolysis revealed that the iodine which was thyroxine-like in its solubility constituted approximately 70 per cent of the total protein-bound iodine, somewhat higher values being encountered in severe hyperthyroidism. In myxedema the thyroxine-like iodine was found to be only a small fraction (20 per cent) of the protein-bound iodine. The non-thyroxine iodine was considered diiodotyrosine-like (14). More recently, Salter and Johnston (20), on the basis of results obtained on adding thyroxine to the serum of patients, have questioned whether the circulating thyroid hormone in man is free thyroxine. At acid $\mathrm{pH}$, thyroxine added to the sera of euthyroid and myxedematous subjects was only partially precipitated with the proteins by acetone, but acetone treatment of the acidified serum of a hyperthyroid patient resulted in quantitative precipitation of the organic iodine. It was inferred that the circulating hormone in hyperthyroidism is not free thyroxine.

The present work is an investigation by partition chromatographic methods of the nature of the plasma protein-bound iodine in patients with Graves' disease.

\section{METHODS}

Studies were conducted on six hyperthyroid patients who received therapeutic doses (10 to 15 millicuries each) of carrier-free radioactive sodium iodide $\left(\mathrm{I}^{221}\right)$. All of the patients had been previously treated with propylthiouracil or other antithyroid drugs; the administration of the antithyroid medication had been discontinued not less than three days prior to the administration of the radioiodine, and in some cases its use was resumed 48 hours after the therapeutic dose. Samples of venous blood were obtained from each patient at time intervals ranging between 48 and 240 hours after the ingestion of the isotope; the blood was placed in a centrifuge tube containing a few milligrams of dry heparin and immediately centrifuged. The plasma was drawn off, and a $1.0 \mathrm{cc}$. aliquot pipetted into a standard vial for measurement of the total content of $I^{12}$. The activity of this, and all other liquid samples, was estimated by means of a lead-shielded Sylvania gamma-ray counting tube, as described by Raben (21), connected with a scaling circuit of conventional type. Corrections for variations in sample volume were made by reference to a calibration curve referring counts in volumes ranging between 0.2 and $3.0 \mathrm{cc}$. to the standard volume $1.0 \mathrm{cc}$.

Extraction procedure: The procedure devised for extraction of the plasma organic iodine consisted of trichloroacetic acid precipitation of the proteins (9) and butanol extraction (22) of the acid aqueous suspension of the washed precipitate. To $2.0 \mathrm{cc}$. plasma in a $12 \mathrm{cc}$. graduated centrifuge tube was added, with stirring, $0.6 \mathrm{cc}$. ice-cold 40 per cent trichloroacetic acid. The mixture was centrifuged and the precipitate washed twice with 3-5 cc. of cold 5 per cent trichloroacetic acid, centrifuging each time and removing the liquid phase as completely as possible by means of a rubber-bulb pipette terminating in a finely drawn tip. The original supernatant liquid and the washings were combined, the volume noted, and the radioactivity of a suitable aliquot determined. The precipitate was suspended in 1 cc. of water, a few drops of $2 \mathrm{~N} \mathrm{NaOH}$ added, and the $\mathrm{pH}$ adjusted to approximately 3 by adding $2 \mathrm{~N} \mathrm{HCl}$ drop by drop. The suspension was then successively extracted three or four times by shaking vigorously each time with a 2 cc. portion of $n$-butanol saturated with water. The phases were separated by centrifuging. The water-saturated solvent was used in order to prevent the reduction in volume of the aqueous phase that otherwise would occur. The combined butanol extracts were then washed by shaking with 3 cc. of water acidified with 4 or 5 drops $4 \mathrm{~N} \mathrm{HCl}$, a pinch of $\mathrm{NaCl}$ crystals was added to reduce the formation of emulsion, and the butanol layer, which had a pale green color, was separated by centrifugation. The volumes of the butanol and aqueous phases were measured and the radioactivity of appropriate aliquots of each determined. When larger volumes of plasma were used, the procedure was scaled up by the use of proportionately larger volumes of reagents. The butanol extract was evaporated to dryness in vacuum at room temperature and the residue dissolved in $0.5 \mathrm{cc}$. of a solution of butanol : acetic acid: water of composition $70: 15: 15$, respectively, by volume. ${ }^{3}$ The solution was cooled in ice to induce separation of excess salt and centrifuged; this solution was employed in the subsequent chromatographic studies.

In several experiments, in addition to the procedure described above, direct plasma extraction with butanol

${ }^{3}$ In order to keep the volume of the final solution as small as possible and thus facilitate the subsequent chromatographic procedures, quantitative recovery in the butanol-acetic acid-water solution of all the $I^{121}$ in the residue was not generally attempted. In one experiment a solvent volume of $1.0 \mathrm{cc}$. in three divided portions achieved recovery of $\mathbf{9 6}$ per cent of the radioactivity in the original butanol extract. 
was done, the extraction being performed with five successive portions, each of twice the volume of the plasma sample. The combined butanol fractions were evaporated to dryness and the residue taken up in the manner described.

Paper chromatography: A modification of the ascending one-dimensional technique of Williams and Kirby (23) was used. The plasma extract was applied to the paper from a capillary tube so as to produce a spot about $5 \mathrm{~mm}$. in diameter, replicate spots being applied $6 \mathrm{~cm}$. apart along a pencil line $3 \mathrm{~cm}$. above and parallel to the bottom of a rectangular sheet of Whatman No. 1 Filter paper $40 \mathrm{~cm}$. long and $25 \mathrm{~cm}$. wide. The spots were circled in pencil, dried under a fine stream of air at room temperature, and the solutions re-applied to the same spots, the procedure being repeated several times to increase the amount of material applied to the paper. To one spot was added 5-10 cu. $\mathrm{mm}$. of a solution in butanol-acetic acid containing synthetic crystalline thyroxine (Roche-Organon), 3,5-diiodotyrosine (HoffmannLaRoche), 3-monoiodo-1-tyrosine (prepared by the method of Harington and Pitt-Rivers [24]), and potassium iodide; the quantity of each organic carrier added was of the order of 0.1 micromole. In several experiments, N-acetyl-1-thyroxine 4 was added as a carrier with the other components. Each large sheet of paper contained two duplicate plasma extract spots, without added carrier, a third such spot with added carrier and a fourth spot of the carrier solution alone. The paper was creased longitudinally in the center so that the sides formed an angle of about $60^{\circ}$ and placed upright in a Pyrex cylinder (18 inches tall and 6 inches in diameter) containing $100 \mathrm{cc}$. of solvent, covered with a closelyfitting plate glass lid, and allowed to remain in the jar at room temperature for 16-20 hours, at which time the solvent front had ascended $25-30 \mathrm{~cm}$. The solvent found most suitable was $n$-butanol: glacial acetic acid: water in 75:10:15 proportion by volume. Several chromatograms were also developed with the solvent $n$-pentanol: pyridine: $\mathrm{H}_{2} \mathrm{O}, 40: 40: 15$. When the solvent front had ascended to the proper height, the paper was removed, and, after the solvent front had been marked in pencil, was air dried in a hood at room temperature, cut into longitudinal strips $6 \mathrm{~cm}$. wide with the origin of each spot equidistant from the long edges, and each strip marked off in centimeters from the origin to the line of solvent front. The paper was then drawn through a folded lead shield equipped with a rectangular slit $1 \mathrm{~cm}$. wide and $5 \mathrm{~cm}$. long, fixed immediately beneath a thinwindowed Geiger-Muller tube, so that the radioactivity of each $1 \mathrm{~cm}$. length of paper could be determined. The papers were then sprayed with ninhydrin ( 0.25 per cent solution in water-saturated butanol) and the color developed by heating in an oven at $100^{\circ}$ for several minutes. Acetylthyroxine, which gave no color with ninhydrin, was located by streaking the paper first with a con-

4 A sample of this compound, prepared by Dr. Rosalind V. Pitt-Rivers, was supplied through the courtesy of Dr. Fritz Lipmann. centrated aqueous solution of freshly prepared diazotized sulfanilic acid and then with 2.5 per cent sodium carbonate solution (25); a fading red color was produced. Iodide carrier was detected by streaking with silver nitrate solution. All $R_{\text {values }}$ (26) were obtained by measuring from the origin to the linear center of radioactivity or of color.

Radioautographs: Two-dimensional chromatograms of plasma extracts from two patients with added carrier thyroxine, diiodotyrosine and monoiodotyrosine were prepared by the ascending method (23), developing with butanol-acetic solvent in one direction and $n$-pentanolpyridine in the other. After drying, the paper was placed directly on a sheet of no-screen X-Ray Film; film and paper were aligned by punching holes through both in opposite corners, and allowed to remain in a paper exposure holder for three to five days, when the film was developed and the paper sprayed with ninhydrin.

Chromatography on cellulose columns: The use of cellulose columns has been found helpful in the resolution of substances labelled with $I^{m}$ (27). Columns of cellulose (Solka-Floc BW-200) $50 \mathrm{~cm}$. high and $1.2 \mathrm{~cm}$. in diameter were prepared by packing under a pressure of $50 \mathrm{~cm}$. of mercury and equilibrating with $75: 10: 15$ butanol : acetic acid: water solvent until 3-5 column volumes had passed through (28). A 0.3 cc. aliquot of a butanol plasma extract was added to the column, washed in with two $0.5 \mathrm{cc}$. portions of solvent and the column allowed to drip under a pressure head of $3 \mathrm{~cm}$. solvent. After collection of a $20 \mathrm{cc}$. forefraction, effluent fractions each of $0.5 \mathrm{cc}$. volume were collected in flatbottomed test tubes of uniform diameter, an automatic fraction collector operating on a constant time interval basis being used for this purpose. The radioactivity of the effluent liquid fractions was determined in the collecting tube by gamma-ray counting, as described above, without need for transfer. The contents of the three tubes containing the peak of radioactivity were evaporated to dryness in vacuum, taken up in a small volume of solvent, carrier thyroxine added, and chromatographed on paper. In another experiment, crystalline thyroxine was added to a plasma-protein butanol extract and this solution subjected to chromatography on a column. After measurement of radioactivity of the effluent fractions, photometric ninhydrin determinations were performed on each fraction (29).

\section{RESULTS}

Table I indicates the data obtained in each patient relating the dose of $\mathrm{I}^{131}$ and the time after its administration when the blood was sampled to the total plasma radioactivity, its separation into trichloroacetic acid-soluble and insoluble fractions, and the butanol extractability of the latter. Serial studies carried out on successive samples of blood from patient No. 6 indicating the predominance of acid-soluble inorganic $\mathrm{I}^{131}$ during the first eight hours following isotope ingestion and its subse- 
TABLE I

Concentration and distribution of labelled iodine in plasma after administration of $I^{1 n}$

\begin{tabular}{|c|c|c|c|c|c|c|c|c|c|c|}
\hline \multirow{2}{*}{ Patient } & \multirow{2}{*}{$\underset{\text { Ime }}{\text { Dope }}$} & \multirow{2}{*}{$\begin{array}{c}\text { Time blood } \\
\text { drawn after } \\
\text { Imy } \\
\text { adminis- } \\
\text { tration }\end{array}$} & \multirow{2}{*}{$\begin{array}{l}\text { Plasma Im } \\
\text { m. per ce. } \\
\text { per mc. } \\
\text { administered* }\end{array}$} & \multirow{2}{*}{$\begin{array}{c}\text { Total Im } \\
\text { in plasma } \\
\text { aample } \\
\text { fractionatedt }\end{array}$} & \multicolumn{2}{|c|}{$\begin{array}{l}\text { Triehloroacetic } \\
\text { acid-oluble }\end{array}$} & \multicolumn{2}{|c|}{$\begin{array}{l}\text { Trichloroacetic } \\
\text { acid-ineoluble }\end{array}$} & \multicolumn{2}{|c|}{$\begin{array}{l}\text { Combined butanol } \\
\text { extracts }\end{array}$} \\
\hline & & & & & cts./sect $t$ & $\begin{array}{c}\text { \% of } \\
\text { total } \\
\text { planema } \\
\text { Im }\end{array}$ & cts./sect $t$ & $\begin{array}{c}\% \text { of } \\
\text { total } \\
\text { plapma } \\
\text { Im }\end{array}$ & cta/sect $t$ & $\begin{array}{l}\% \text { of tri- } \\
\text { chloroncetic } \\
\text { acid- } \\
\text { insoluble }\end{array}$ \\
\hline $\begin{array}{l}1 \\
2 \\
3 \\
4 \\
5 \\
6\end{array}$ & $\begin{array}{l}\text { (mc.) } \\
10 \\
10 \\
\\
12.5 \\
10 \\
15 \\
14.7\end{array}$ & $\begin{array}{l}\text { (hours) } \\
48 \\
48 \\
65 \\
72 \\
792 \\
4 \\
8 \\
24 \\
72 \\
240\end{array}$ & $\begin{array}{r}7.95 \times 10^{-8} \\
64.5 \times 10^{-8} \\
22.9 \times 10^{-8} \\
19.7 \times 10^{-8} \\
11.9 \times 10^{-8} \\
5.1 \times 10^{-8} \\
1.44 \times 10^{-8} \\
1.22 \times 10^{-8} \\
3.92 \times 10^{-8} \\
8.10 \times 10^{-8}\end{array}$ & $\begin{array}{l}\quad(u c) \\
0.134 \\
1.09 \\
1.08 \\
2.05 \\
1.29 \\
0.358 \\
0.222 \\
0.0621 \\
0.050 \\
0.133 \\
0.249\end{array}$ & $\begin{array}{r}0.5 \\
5.9 \\
6.4 \\
11.1 \\
12.1 \\
1.7 \\
53.7 \\
15.0 \\
1.7 \\
1.5\end{array}$ & $\begin{array}{l}1.4 \\
2 \\
2.2 \\
2.0 \\
3.4 \\
1.8 \\
89.5 \\
89.5 \\
12.6 \\
2.2\end{array}$ & $\begin{array}{r}35.7 \\
290.1 \\
285.6 \\
543.9 \\
335.9 \\
95.1 \\
6.3 \\
1.8 \\
11.8 \\
65.8\end{array}$ & $\begin{array}{l}98.6 \\
98 \\
97.8 \\
98 \\
96.6 \\
98.2 \\
10.5 \\
10.5 \\
87.4 \\
97.8\end{array}$ & $\begin{array}{l}31.6 \\
268 \\
290.8 \\
522.3\end{array}$ & $\begin{array}{r}89 \\
92 \\
102 \\
96\end{array}$ \\
\hline
\end{tabular}

* Corrected for decay to the time of ingestion of $\mathrm{I}^{\mathbf{m}}$.

$\dagger 1$ count per sec. in $1.0 \mathrm{cc}$. volume $=3.70 \times 10^{-3}$ microcuries.

quent great diminution concurrent with the increase, both relative and absolute, of protein-bound $I^{131}$ are in general agreement with the observations of McConahey and his colleagues (8). After 48 hours following administration of the radioactive iodine, 97-99 per cent of the plasma I ${ }^{181}$ is protein-bound. The degree of completeness of the butanol extraction of the protein-bound ${ }^{181}$, as indicated in the table, approximates 95 per cent. The method of trichloroacetic acid precipitation and butanol extraction of the suspended insoluble precipitate was more efficient and complete in removing $\mathrm{I}^{131}$ from the aqueous phase than the method of direct plasma extraction with butanol. In two instances (patients Nos. 1 and 2), in which by the former method 89 and 97 per cent of the acid-insoluble iodine was extracted, the latter method yielded values of 70 per cent and 89 per cent of the total plasma radioiodine, figures comparable to those reported in butanol extraction of rat plasma $(12,17,18)$.

The final washing of the combined butanol extracts with dilute acid was found to be essential. This washing removed virtually no radioactivity; if it was omitted, the green butanol solution assumed a gelatinous consistency which made manipulation difficult and rendered chromatograms of the redissolved, evaporated solutions unsatisfactory, $R_{\mathbf{F}}$ values of added carriers becoming markedly diminished and the bands distorted. The nature of the green color of the butanol solutions is not clear. Preliminary attempts to extract it from the radioactivity by the use of several organic solvents were unsuccessful, and on column chromatography, the rate of downward movement of the green band is very similar to that of the radioactivity. Butanol extracts of whole plasma did not exhibit the green color.

One-dimensional paper chromatography indicated that the radioactivity in the butanol extract of the protein-bound $\mathrm{I}^{181}$ had an $R_{\mathbb{T}}$ value identical to that of crystalline thyroxine, whether the latter was added to the active extract chromatographed or was run with an extract parallel to those without added carriers. In every case, only one area of radioactivity appeared on the paper, at the position corresponding to the location of thyroxine. No radioactivity was detectable at the bands corresponding to diiodotyrosine, monoiodotyrosine, or iodide. This is in contrast to results obtained in chromatography of rat plasma extracts in collidine (18), where appreciable amounts of iodide and small amounts of diiodotyrosine were encountered, presumably due to decomposition of thyroxine during chromatography. No iodide spot would be expected (unless decomposition during chromatography occurred), under the conditions of the present work because 1) the trichloroacetic acid precipitate alone is extracted, and 2) a step in the procedure involves evaporation of an acid solution to dryness. Representative chromatograms are shown in Figure 1. 
In the butanol-acetic acid-water chromatographic solvent the approximate $R_{F}$ values of potassium iodide, monoiodotyrosine, diiodotyrosine, thyroxine, and acetylthyroxine are, respectively, $0.16,0.42,0.53,0.78$, and 0.88 ; the actual values vary somewhat with the age of the solvent but in every case the $R_{F}$ of thyroxine was equal to the $R_{F}$ of the radioactivity. The iodinated amino acid carriers can be recognized not only by their distinct $R_{F}$ values but also by the differences in ninhydrin color they produce on dry paper, monoiodotyrosine being reddish-purple, diiodotyrosine blue, and thyroxine bluish-gray. Ninhydrin treatment of the chromatogram run without added carriers revealed a long, faint pink streak in the center of the paper and a very faint purple at the origin; the quantity of thyroxine in the aliquot of plasma extract chromatographed was far too minute to be detectable by a colorimetric ninhydrin reaction. The paper without carriers also presented a colorless, lipid-like, hydrophobic spot free of $I^{131}$ at $R_{F}=0.95$, detectable by the formation of water droplets on streaking this region of the paper with aqueous sodium carbonate solution. The rates of movement of diiodotyrosine and thyroxine added to butanol extracts of plasma proteins were greater than those exhibited by these substances in acid butanol solution, while monoiodotyrosine and iodide were unaffected by the presence of the plasma constituents; thus, the $R_{F}$ of diiodotyrosine and thyroxine added to a dried plasma butanol extract spot were found
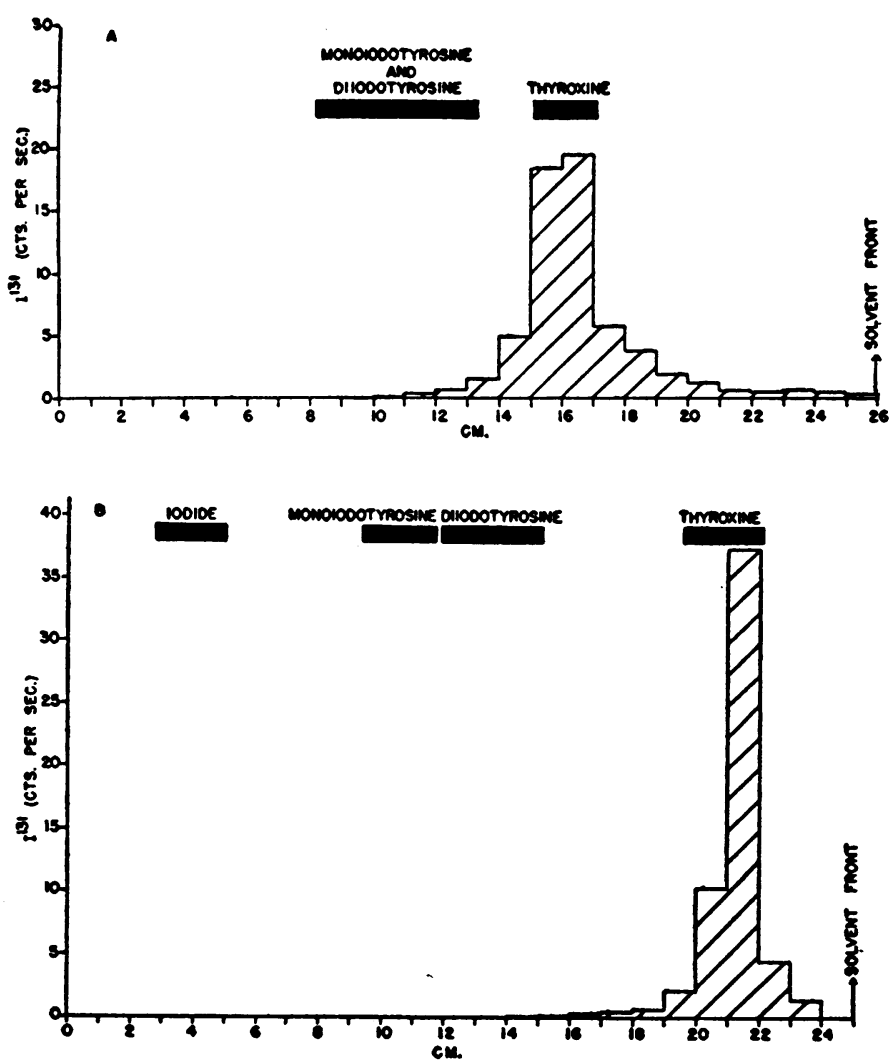

Fig. 1. Distribution of Radioactivity on Filter Paper Chromatograms of Butanol Extracts of Aqueous Suspensions of Plasma Trichloroacetic Acid Precipitate

A. Solvent: $n$-pentanol : pyridine: water, $40: 40: 15$. Carrier added.

B. Solvent : $n$-butanol : glacial acetic acid : water, $75: 10: 15$. No added carrier.

Position of added (A) and parallel (B) carriers are indicated by shaded rectangles. 
to be 0.62 and 0.83 , respectively, while these crystalline components without plasma extract showed values of 0.53 and 0.78 . Until the accelerating affect of plasma extract on the movement of thyroxine was appreciated, the concordance of the $R_{F}$ of radioactivity with added thyroxine and the discrepancy between the $R_{F}$ of activity and parallel thyroxine in solution of carrier alone was puzzling. The apparent discrepancy between results with added and parallel carriers was resolved by addition of the carrier solution designed for parallel runs to a spot of plasma extract. In the pentanol-pyridine- $\mathrm{H}_{2} \mathrm{O}$ solvent, the $\mathrm{R}_{\mathrm{F}}$ of thyroxine was found to be 0.61 , as was that of the radioactivity; mono- and diiodotyrosine are incompletely resolved by this solvent and no radioactivity was detected in their combined area.

The $R_{F}$ values obtained with butanol-acetic acid-water developing solvents were not constant, decreasing with time presumably because of esterification (30). For this reason reliance could not be placed on presumptive identification of an unknown substance by comparison with previously determined $R_{F}$ values of known substances, but only with parallel carriers run at the same time and under the same conditions. It was found useful to employ solvents one or two days old, the rate of change of $R_{F}$ values appearing to be slower after this time.

In addition to comparison of the area of radioactivity with thyroxine on the basis of identity of $R_{F}$, more precise localization was accomplished as follows: After the strip with added carriers had been counted and the color developed by ninhydrin, the grayish-blue thyroxine was cut out of the paper and also adjacent ninhydrin-negative paper areas of approximately equal size. The radioactivity of each piece of paper was then determined. The highest radioactivity was in the ninhydrin-colored thyroxine spot, but detectable amounts were present somewhat peripheral to the outermost zone of ninhydrin color, a reflection of the greater sensitivity of detection achieved by counting as compared with ninhydrin color development (the latter being rather insensitive when used for the demonstration of a compound of molecular weight 777 and containing only one amino group); the greater spread of radioactivity as compared with the corresponding color spot is illustrated in Figure 1.
Chromatograms prepared from direct butanol extracts of plasma were similar to those obtained with extracts of the trichloroacetic acid precipitate; only one area of radioactivity was detected on the paper, corresponding in position with thyroxine. Spraying the paper having no added carrier with ninhydrin revealed a number of discrete ninhydrinreacting areas, all below the position of radioactivity.

Radioautographs prepared from the two-dimensional chromatograms showed complete correspondence in size, form and location of the darkened area on the film with the ninhydrin-reacted thyroxine spot on the paper, with no band visible at areas corresponding to mono- and diiodotyrosine. A faint darkening at the solvent front and a very faint rather diffuse darkening just below the front were noted.

Column chromatography of plasma extract without added carrier yielded a single, smooth effluent curve of activity which emerged in absolute position very similar to the thyroxine peak observed on passage through a similar column of butanol extract of an alkaline hydrolysate of the thyroid gland of a rat previously injected with $I^{181}$ (27). Out of a total of 0.388 microcurie added to the column, 0.366 microcurie was included under this curve, a recovery in a single peak of 95 per cent of the total added radioactivity. Paper chromatography of the pooled fractions constituting the effluent peak demonstrated a single active spot, the $R_{F}$ of which was equal to the $R_{F}$ of both added and parallel crystalline thyroxine. More quantitative evidence for the identical distribution in the continuous partition system between organic and aqueous phases of the radioactively labelled molecule and synthetic thyroxine was afforded by the results of the experiment in which $1.78 \mathrm{mgm}$. thyroxine was added to the butanol extract subjected to passage through the column, and radioactivity and ninhydrin-reacting material estimated on the effluent fractions (Figure 2). The effluent radioactivity emerged in a fairly symmetrical fashion between 24 and $28 \mathrm{cc}$., with a peak at $25.4 \mathrm{cc}$., and 97 per cent of the activity added to the column was recovered in this zone; the added thyroxine emerged between the same limits, its curve paralleling that of the radioactivity with its peak at $25.4 \mathrm{cc}$., and with 106 per cent recovery as determined by its 
ninhydrin equivalent. The value for each tube of the ratio $\frac{\text { thyroxine }}{I^{131}}$, experimentally determined by dividing the corrected Klett reading of ninhydrin color for each tube by the corresponding radioactive count, was found to be constant within the limits of the errors of counting and analysis, a quantitative indication of the readily apparent similarity between the curves, as illustrated in Figure 2. The slight deviation of ninhydrin points at the lower end of the descending limb of the curve in Figure 2 may be due to the presence of a small amount of endogenous ninhydrin-reacting material in the butanol extract.

\section{DISCUSSION}

The results of the experimental work indicate that virtually all the radioactive iodine in the plasma of patients with Graves' disease, who have received therapeutic doses of $\mathrm{I}^{131}$ two to ten days previously, exists as a single substance precipitating with the plasma proteins but easily and quanti- tatively separable from the precipitate, and that this substance is indistinguishable from thyroxine in its chromatographic behavior in two different partition systems. These findings are in general agreement with results obtained on the plasma iodine of rats by essentially similar methods (12, 17-19). A negative statement that would appear to be warranted is that no radioactive monoor diiodotyrosine and no acetylthyroxine are present in plasma in significant amounts; the quantitative paper strip method as employed here is sensitive enough to detect radioactivity in the locations of these compounds if amounts as small as 0.5 per cent of the total were present, yet none was detectable either by direct counting or by radioautographs.

Chromatographic methods whether by adsorption or partition are peculiarly adapted to the unequivocal demonstration of the non-identity of an unknown compound and known substances suspected of being identical with it. Rigorous proof of the identity of an unknown substance whose be-

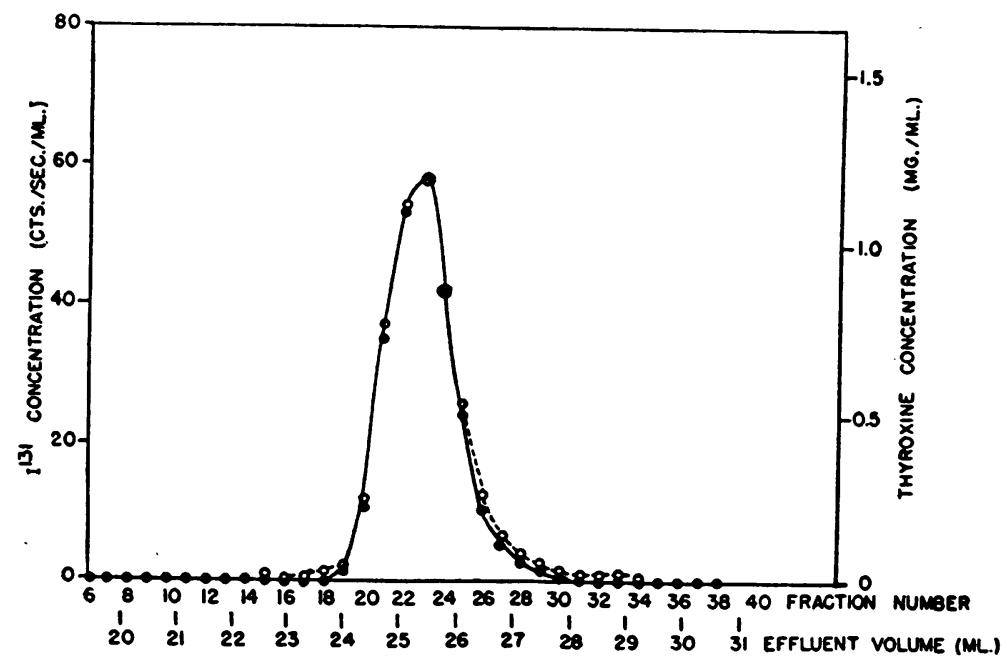

Fig. 2. Effluent Curves of Radionctivity (Solm Circles-Unbroken Line) and of Thyroxine (Open Circles-Broken Line) from a Cellulose Column 50 CM. High and 1.2 CM. in Diameter

Solvent: $n$-butanol : glacial acetic acid: water, $75: 10: 15$. A concentrated butanol extract $(0.35 \mathrm{cc}$.) of the trichloroacetic acid precipitate from the plasma of patient No. 3 containing 0.280 microcurie $I^{1 m}$ and $1.78 \mathrm{mgm}$. added thyroxine was placed on the column. The effluent fractions between 24 and 27.5 cc. contained 0.272 microcurie and $1.89 \mathrm{mgm}$. thyroxine (ninhydrinequivalent). For successive fractions 19 through 27 , inclusive, the values of the corresponding graphical representations of the ratio

$$
\frac{\text { thyroxine concentration }}{I^{15} \text { concentration }}
$$

are : $1.22,1.07,1.05,1.02,1.00,0.99,1.07,1.18$, and 1.29 . 
havior on a chromatogram seems the same as a compound of known structure on the basis of position, both absolute and in relation to other known substances, would require isolation of the unknown material, crystallization, and characterization by elementary analysis and standard chemical methods (31). The minute concentration of protein-bound iodine in plasma renders such positive methods impractical. Nevertheless, in systems in which the general nature of the compounds likely to be encountered is known, correct identification, with a high degree of probability, may be made by analysis of chromatographic behavior in comparison with known substances (32). The constancy of the relationship demonstrated between the concentration of added thyroxine and of $\mathrm{I}^{181}$ in the effluent fractions of a butanol extract of plasma protein is very suggestive evidence in favor of the concept that the endogenous compound is indeed thyroxine; evidence of this kind is somewhat akin to that derived from repeated crystallization to constant specific activity of labelled material with added carrier (12). The possibility, remote though it may appear, that added thyroxine and the labelled plasma constituent run pari passu in the column and also cocrystallize fortuitously is not excluded (12). The possibility that the paper chromatographic method may not afford a satisfactory resolution between thyroxine and a small thyroxine-peptide has been mentioned by Chaikoff and his associates (18) as a point to be investigated before unqualified acceptance can be accorded to the identity of thyroxine with the circulating thyroid hormone. In this connection the good resolution achieved in the present work between $\mathrm{N}$-acetylthyroxine and thyroxine is encouraging. A considerable difference in distribution coefficients between immiscible solvents of rat plasma $I^{131}$ and of a thyroxine-peptide of uncertain composition has been observed (12).

The probability that exchange reaction between $I^{181}$ contained in the protein-bound iodine and added thyroxine occurs during chromatography is small, since the $R_{F}$ values with and without added thyroxine are the same, and since the addition of other iodinated amino acids and iodide as carrier results in no activity in these carriers. Radiochemical exchange and decomposition have also been eliminated as confusing factors in the rat plasma $(17,19)$.
In order to achieve a sufficiently high concentration of plasma protein-bound $\mathrm{I}^{131}$ to make chromatographic study practical, administration of a dose of radioiodine much larger than the usual tracer dose is almost mandatory, and the procedure is thus necessarily limited to individuals undergoing treatment for Graves' disease. In comparable studies in animals, doses of 80-150 microcuries per rat have been employed $(17,18)$ which are proportionally larger than the 10-15 millicuries administered to human subjects in the present study. It is unlikely that the conclusions regarding the nature of the circulating thyroid hormone which were derived from observations made in patients receiving therapeutic doses of $\mathrm{I}^{131}$ would be different had the study been conducted with tracer doses potentially less destructive to the thyroid gland. Radioautographs of paper chromatograms of rat plasma extracts have revealed identical patterns whether each animal received 1 or 100 microcuries of $I^{181}$ (20).

Whether the terms "hormonal iodine," "protein-bound iodine," and "precipitable iodine" of plasma or serum are synonymous is not completely established (33). The view that the circulating thyroid hormonal iodine comprises a large fraction rather than all of the plasma protein-bound iodine rests on the observations that there is a small but definite concentration in cases of myxedema $(14,33)$, that probably not all the organic iodine is ordinarily extractable with butanol and not re-extractable with Blau's reagent $(13,14)$, that administered organic iodine compounds such as are used in cholecystography and myelography may produce elevated protein-bound iodine concentrations for considerable periods of time (34), and that ingestion of even inorganic iodide may result in increase of the serum protein-bound iodine concentration, the increment clearly not being thyroxine as shown by its solubility properties (35). The plasma protein-bound iodine may, therefore, on occasion represent more than one component. The results of the present study of labelled plasma iodine indicate that in Graves' disease the circulating thyroid hormone is indistinguishable from thyroxine, and there is little reason to suspect a qualitative difference in the nature of the hormone in other individuals. It would therefore appear that the plasma thyroxine is more specifically 
identifiable with the circulating thyroid hormone in man than is the protein-bound iodine.

\section{SUM MARY}

1. Studies of the plasma of six hyperthyroid patients two to ten days following the administration of therapeutic doses of radioactive iodine $\left(I^{131}\right)$ indicate that 97 to 99 per cent of the labelled iodine is protein-bound.

2. Methods are described for the quantitative extraction from plasma of the labelled proteinbound iodine and for its characterization by chromatographic technics using filter paper and cellulose columns.

3. Practically all of the labelled organic iodine in the plasma has been found to exist as a single substance indistinguishable from thyroxine.

4. No monoiodotyrosine, diiodotyrosine nor acetylthyroxine were detectable as constituents of the plasma protein-bound iodine.

5. The evidence would indicate that the circulating thyroid hormone in Graves' disease is thyroxine.

\section{ACKNOWLEDGMENT}

The author is indebted to Dr. E. B. Astwood for many helpful suggestions.

\section{REFERENCES}

1. Lowenstein, B. E., Bruger, M., and Hinton, J. W., The protein-bound plasma iodine in patients with thyroid disease. I. Correlation with basal heat production. J. Clin. Endocrinol., 1944, 4, 268.

2. Salter, W. T., Bassett, A. M., and Sappington, T. S., Protein-bound iodine in blood. VI. Its relation to thyroid function in 100 clinical cases. Am. J. M. Sc., 1941, 202, 527.

3. Man, E. B., Smirnow, A. E., Gildea, E. F., and Peters, J. P., Serum iodine fractions in hyperthyroidism. J. Clin. Invest., 1942, 21, 773.

4. Winkler, A. W., Riggs, D. S., Thompson, K. W., and Man, E. B., Serum iodine in hyperthyroidism, with particular reference to the effects of subtotal thyroidectomy. J. Clin. Invest., 1946, 25, 404.

5. Lowenstein, B. E., Bruger, M., Hinton, J. W., and Lough, W. G., The protein-bound plasma iodine in patients with thyroid disease. II. The effect of thiouracil. J. Clin. Endocrinol., 1945, 5, 181.

6. Williams, R. H., and Bissell, G. W., Thiouracil in the treatment of thyrotoxicosis. New England J. Med., 1943, 229, 97.

7. Freedberg, A. S., Ureles, A., and Hertz, S., Serum level of protein-bound radioactive iodine $\left(I^{210}\right)$ in the diagnosis of hyperthyroidism. Proc. Soc. Exper. Biol. and Med., 1949, 70, 679.

8. McConahey, W. F., Keating, F. R., Jr., and Power, M. H., The behaviour of radioiodine in the blood. J. Clin. Invest., 1949, 28, 191.

9. Chaikoff, I. L., Taurog, A., and Reinhardt, W. O., The metabolic significance of protein-bound iodine in plasma; a study of its concentration under various conditions and of its rate of formation as measured with radioactive iodine. Endocrinology, 1947, 40, 47.

10. Lerman, J., Iodine components of the blood. Circulating thyroglobulin in normal persons and in persons with thyroid disease. J. Clin. Invest., 1940, 19, 555.

11. Trevorrow, V., Studies on the nature of the iodine in blood. J. Biol. Chem., 1939, 127, 737.

12. Taurog, A., and Chaikoff, I. L., The nature of the circulating thyroid hormone. J. Biol. Chem., 1948, 176, 639.

13. Danowski, T. S., Mateer, F., Weigand, F. A., Peters, J. H., and Greenman, J. H., Serum iodine fractions in subjects receiving potassium iodide in small dosage. J. Clin. Endocrinol., 1950, 10, 532.

14. Bassett, A. M., Coons, A. H., and Salter, W. T., Protein-bound iodine in blood. V. Naturally occurring iodine fractions and their chemical behavior. Am. J. M. Sc., 1941, 202, 516.

15. Leland, J. P., and Foster, G. L., A method for the determination of thyroxine in the thyroid. J. Biol. Chem., 1932, 95, 165.

16. Elmer, A. W., Luczynski, Z., and Scheps, M., Sur la thyroxinémie normale chez l'homme et chez l'animal. Compt. rend. Soc. de biol., 1934, 115, 1714.

17. Laidlaw, J. C., Nature of the circulating thyroid hormone. Nature, 1949, 164, 927.

18. Taurog, A., Chaikoff, I. L., and Tong, W., The nature of plasma iodine as revealed by filter paper partition chromatography. J. Biol. Chem., 1950, 184, 99.

19. Gross, J., Leblond, C. P., Franklin, A. E., and Questel, $J$. $H$., Presence of iodinated amino acids in unhydrolyzed thyroid and plasma. Science, 1950, 111, 605.

20. Salter, W. T., and Johnston, M. W., Tracing the thyroid hormone in peripheral tissues. J. Clin. Endocrinol., 1948, 8, 911.

21. Raben, M. S., Microdetermination of iodine employing radioactive iodine. Analyt. Chem., 1950, 22, 480.

22. Blau, N. F., The determination of thyroxine in the thyroid gland. J. Biol. Chem., 1933, 102, 269.

23. Williams, R. J., and Kirby, H., Paper chromatography using capillary ascent. Science, 1948, 107, 481.

24. Harington, C. R., and Pitt-Rivers, R. V., Mono-iodotyrosine. Biochem. J., 1944, 38, 320.

25. Dent, C. E., The amino-aciduria in Fanconi syn- 
drome. A study making extensive use of techniques based on paper partition chromatography. Biochem. J., 1947, 41, 240.

26. Consden, R., Gordon, A. H., and Martin, A. J. P., Qualitative analysis of proteins: a partition chromatographic method using paper. Biochem. J., 1944, 38, 224.

27. Rosenberg, I. N. Unpublished data.

28. Peterson, D. H., and Reineke, L. M., The chemistry of circulin; chromatographic isolation of the amino acid constituents with powdered cellulose. J. Biol. Chem., 1949, 181, 95.

29. Moore, S., and Stein, W. H., Photometric ninhydrin method for use in the chromatography of amino acids. J. Biol. Chem., 1948, 176, 367.

30. Benson, A. A., Bassham, J. A., Calvin, M., Goodale, T. C., Haas, V. A., and Stepka, W., The path of carbon in photosynthesis. V. Paper chromatography and radioautography of the products. J. Am. Chem. Soc., 1950, 72, 1710.
31. Stein, W. H., and Moore, S., Chromatography of amino acids on starch columns. Separation of phenylalanine, leucine, isoleucine, methionine, tyrosine, and valine. J. Biol. Chem., 1948, 176, 337.

32. Stein, W. H., and Moore, S., Chromatographic determination of the amino acid composition of proteins. Symposia on Quantitative Biology. Biological Laboratory, Cold Spring Harbor, New York, 1950, 14, 179.

33. Winkler, A. W., Disorders of the Thyroid Gland, in Duncan, G. G., Diseases of Metabolism. W. B. Saunders, Philadelphia, 1947, p. 912.

34. Riggs, D. S., Serum protein-bound iodine as a diagnostic aid. Tr. Am. A. Study of Goiter, 1947, p. 137.

35. Danowski, T. S., Johnston, S. Y., and Greenman, J. H., Alterations in serum iodine fractions induced by the administration of inorganic iodide in massive dosage. J. Clin. Endocrinol,, 1950, 10, 519. 